\title{
Carbon monoxide diffusing capacity in polycythaemia
} \section{rubra vera}

\author{
AP GREENING, K PATEL, AWG GOOLDEN, AJ MUNRO, JMB HUGHES \\ From the Departments of Medicine and Radiotherapy, Royal Postgraduate Medical School, Hammersmith \\ Hospital, London
}

\begin{abstract}
The diffusing capacity of the lung, or transfer factor, for carbon monoxide (TLCO) was measured in 12 patients with polycythaemia rubra vera. This was significantly raised (mean $152 \%$ predicted, SEM $\pm 14 \%$ ) and remained so even after correction to a standard haemoglobin concentration of $14.6 \mathrm{~g} / \mathrm{dl}$ (mean $139 \%$ predicted, SEM $\pm 13 \%$ ). Serial measurements of TLCo on two patients after treatment of polycythaemia rubra vera showed a greater fall in relation to haemoglobin concentration than would have been predicted on theoretical grounds if the increases in TLCO had been due entirely to the increased haemoglobin concentration. The pulmonary capillary blood volume (estimated from TLCO) also fell in these two patients after treatment. There was a strong correlation between TLCO and the technetium-99m-labelled red cell volume for the seven men $(r=0.92 ; p<0.01)$ and five women $(r=0.99 ; p<0.001)$ when studies were performed on the same day. In patients with polycythaemia rubra vera who have no evidence of coexistent pulmonary disease the pulmonary capillary bed appears to share in the expansion of the body blood volume. The single-breath TLCO test may act as a convenient and simple monitor for the response of the disease to treatment.
\end{abstract}

The total lung diffusing capacity, or transfer factor, for carbon monoxide (TLCO) is determined by the membrane-diffusing capacity (DM), the reaction rate of carbon monoxide with oxyhaemoglobin $(\theta)$, and the pulmonary capillary blood volume (VC). Roughton and Forster ${ }^{1}$ proposed the equation

$$
\frac{1}{\mathrm{TLCO}}=\frac{1}{\mathrm{DM}}+\frac{1}{\theta \cdot \mathrm{VC}}
$$

to describe this relation.

In polycythaemia rubra vera the increased haemoglobin concentration should result in an increase in the reaction rate of carbon monoxide with oxyhaemoglobin, which would lower the red cell resistance and increase the TLCO. Early observations $^{2}$ did not support this prediction but full methodological and clinical details were not given. Later workers have demonstrated an elevated TLCO. ${ }^{34}$ Both groups attributed the elevated diffusing capacity to the high haemoglobin concentration. We had observed that some patients with polycythaemia rubra vera had an elevated TLCO even after correction for the high haemoglobin con-

Address for reprint requests: Dr JMB Hughes, Royal Postgraduate Medical School, Hammersmith Hospital, Ducane Road, London W12 0HS. centration. In view of the work of Cotes $e t a^{5}$ and Clark et $a l^{6}$ we now routinely correct to a standard haemoglobin concentration of $14.6 \mathrm{~g} / \mathrm{dl}$, using the equation:

$$
\operatorname{TLCO}(\text { corr })=\text { TLCO (obs). }\left[\frac{\alpha(\mathrm{Hb})+\mathrm{Hb}}{(1+\alpha) \cdot \mathrm{Hb}}\right] \text {, }
$$

where $\alpha=\mathrm{DM} / \mathrm{Vc}$ ratio (assumed to be $0 \cdot 7),(\mathrm{Hb})$ $=$ standard haemoglobin concentration $(14.6 \mathrm{~g} / \mathrm{dl})$, and $\mathrm{Hb}=$ the actual haemoglobin concentration. We have therefore studied the TLCO in patients with polycythaemia rubra vera and examined the response to treatment, with particular reference to the membrane conductance (DM) and pulmonary capillary blood volume (VC).

\section{Methods}

Twelve patients (seven men and five women) were studied (table 1). Patients 1-7 were studied at first presentation or when they relapsed. Patients 8-12 were studied while receiving maintenance therapy 
Table 1 Age, sex, weight, height, haemoglobin concentration, and plasma and red cell volumes for 12 patients with polycythaemia rubra vera at time of first study

\begin{tabular}{|c|c|c|c|c|c|c|c|c|}
\hline \multirow[t]{2}{*}{ Patient No } & \multirow{2}{*}{$\begin{array}{l}\text { Age } \\
(y)\end{array}$} & \multirow[t]{2}{*}{ Sex } & \multirow{2}{*}{$\begin{array}{l}\text { Weight } \\
(\mathrm{kg})\end{array}$} & \multirow{2}{*}{$\begin{array}{l}\text { Height } \\
(m)\end{array}$} & \multirow{2}{*}{$\begin{array}{l}\text { Haemoglobin } \\
\text { concentration } \\
\text { (g/dl) }\end{array}$} & \multirow{2}{*}{$\begin{array}{l}\text { Plasma volume } \\
(\mathrm{ml} / \mathrm{kg})\end{array}$} & \multicolumn{2}{|c|}{ Red cell volume } \\
\hline & & & & & & & $(\mathrm{ml} / \mathrm{kg})$ & (\% predicted) \\
\hline $\begin{array}{c}1 \\
2 \\
3 \\
4 \\
5 \\
6 \\
7 \\
8 \\
9 \\
10 \\
11 \\
12 \\
\text { Mean }\end{array}$ & $\begin{array}{l}38 \\
44 \\
50 \\
54 \\
65 \\
48 \\
59 \\
79 \\
74 \\
81 \\
34 \\
71 \\
58\end{array}$ & $\begin{array}{l}\mathbf{M} \\
\mathbf{M} \\
\mathbf{M} \\
\mathbf{M} \\
\mathbf{M} \\
\mathbf{M} \\
\mathbf{M} \\
\mathbf{F} \\
\mathbf{F} \\
\mathbf{F} \\
\mathbf{F} \\
\mathbf{F}\end{array}$ & $\begin{array}{l}72 \\
75 \\
65 \\
79 \\
66 \\
78 \\
67 \\
45 \\
64 \\
43 \\
45 \\
59 \\
63\end{array}$ & $\begin{array}{l}1.77 \\
1.73 \\
1.69 \\
1.78 \\
1.60 \\
1.76 \\
1.80 \\
1.54 \\
1.60 \\
1.57 \\
1.60 \\
1.50 \\
1.66\end{array}$ & $\begin{array}{l}21 \cdot 0 \\
23.6 \\
21 \cdot 1 \\
19 \cdot 0 \\
19.5 \\
18 \cdot 1 \\
21.7 \\
16.5 \\
15.6 \\
16.9 \\
16.6 \\
16.0 \\
18.8\end{array}$ & $\begin{array}{l}42 \cdot 2 \\
39 \cdot 0 \\
45 \cdot 3 \\
39 \cdot 3 \\
31 \cdot 5 \\
33 \cdot 6 \\
40 \cdot 0 \\
46 \cdot 0 \\
34 \cdot 9 \\
56 \cdot 5 \\
40 \cdot 2 \\
39 \cdot 3 \\
40.7\end{array}$ & $\begin{array}{l}84 \cdot 9 \\
86 \cdot 3 \\
56 \cdot 8 \\
48 \cdot 8 \\
48 \cdot 4 \\
34 \cdot 7 \\
56 \cdot 7 \\
39 \cdot 7 \\
27 \cdot 1 \\
46 \cdot 8 \\
34 \cdot 1 \\
40 \cdot 4 \\
50.4\end{array}$ & $\begin{array}{l}292 \\
308 \\
187 \\
177 \\
166 \\
126 \\
184 \\
159 \\
119 \\
175 \\
128 \\
180 \\
183\end{array}$ \\
\hline
\end{tabular}

(venesection). The diagnosis of polycythaemia rubra vera was made on clinical and haematological criteria. ${ }^{7}$ Pulmonary function tests and measurements of red cell and plasma volumes were performed on all patients on the same day.

Pulmonary function tests-The one-second forced expiratory volume $\left(F E V_{1}\right)$ and the slow vital capacity (VC) were measured on a dry spirometer. Total lung capacity (TLC) was measured in a constantvolume plethysmograph. Predicted values for VC and TLC were taken from Goldman and Becklake. ${ }^{8}$ Alveolar volume (VA) was determined by helium dilution during measurement of the standard single-breath diffusing capacity of the lung for carbon monoxide as set out by Cotes.9 ${ }^{9}$ TLCO was corrected to a standard haemoglobin concentration $(14.6 \mathrm{~g} / \mathrm{dl})$ with the formula of Cotes $e t \mathrm{al}^{\mathrm{s}}$; predicted values were taken from Bradley et al. ${ }^{10}$ With patients 1 and 2 serial pulmonary function tests were carried out after treatment of the polycythaemia rubra vera (by phosphorus-32 and venesection). In addition, TLCO was estimated while they were breathing room air and $100 \%$ oxygen, so that DM and Vc could be calculated. ${ }^{1}$

Red cell and plasma volumes-The red cell and plasma volumes were determined by the isotopic tracer technique with ${ }^{99 m}$ Tc-labelled red cells and ${ }^{125}$ I-labelled albumin respectively. The results were expressed with reference to standard predicted values. ${ }^{11}$ The measurements of red cell and plasma volumes were repeated on patients 1,2 , and 6 during a 12-month period.

\section{Results}

Pulmonary function test results are shown in table 2 . VC, FEV /VC ratio, VA, and TLC were normal, but TLCO was significantly raised (mean $152 \%$ of predicted, SEM $\pm 14 \%$ ). TLCO remained raised even after correction to a standard haemoglobin concentration (mean $139 \%$ of predicted, SEM $\pm 13 \%$ ). Individual results for red cell and plasma volumes are shown in table 1.

A strong correlation was found between TLCO

Table 2 Pulmonary function data for 12 patients with polycythaemia rubra vera at time of first study

\begin{tabular}{|c|c|c|c|c|c|c|c|}
\hline Patient No & $\begin{array}{l}F E V, N C \\
(\%)\end{array}$ & $\begin{array}{l}V C \\
(\% \text { predicted })\end{array}$ & $\begin{array}{l}T L C \\
\text { (\% predicted) }\end{array}$ & $\begin{array}{l}\text { VA } \\
(l B T P S)\end{array}$ & $\begin{array}{l}\text { KCO } \\
\left(\mathrm{mmol} \mathrm{min} \mathrm{mol}^{-1} \mathrm{kPa}^{-1} \mathrm{l}^{-1} \mathrm{BTPS}\right)\end{array}$ & $\begin{array}{l}\text { TLCO } \\
\text { (\% predicted) }\end{array}$ & $\begin{array}{l}\text { TLCO } \\
\text { (Hb corrected) } \\
\text { (\% predicted) }\end{array}$ \\
\hline $\begin{array}{c}1 \\
2 \\
3 \\
4 \\
5 \\
6 \\
7 \\
8 \\
9 \\
10 \\
11 \\
12 \\
\text { Mean }\end{array}$ & $\begin{array}{l}76 \\
73 \\
78 \\
86 \\
67 \\
63 \\
67 \\
63 \\
80 \\
73 \\
86 \\
76 \\
74\end{array}$ & $\begin{array}{r}100 \\
97 \\
102 \\
93 \\
93 \\
115 \\
96 \\
85 \\
58 \\
89 \\
85 \\
93 \\
92\end{array}$ & $\begin{array}{r}93 \\
94 \\
115 \\
90 \\
111 \\
126 \\
100 \\
97 \\
= \\
- \\
\overline{103}\end{array}$ & $\begin{array}{l}6 \cdot 5 \\
6 \cdot 3 \\
6 \cdot 8 \\
5 \cdot 2 \\
6 \cdot 6 \\
8 \cdot 1 \\
7 \cdot 1 \\
3 \cdot 2 \\
2 \cdot 3 \\
3.0 \\
4 \cdot 7 \\
3.9 \\
5 \cdot 3\end{array}$ & $\begin{array}{l}2.5 \\
3.3 \\
1.9 \\
2.4 \\
1.2 \\
1.0 \\
1.6 \\
1.8 \\
2.2 \\
2.2 \\
2.4 \\
2.0 \\
2.0\end{array}$ & $\begin{array}{r}150 \\
200 \\
149 \\
128 \\
100 \\
77 \\
116 \\
190 \\
121 \\
220 \\
150 \\
226 \\
152\end{array}$ & $\begin{array}{r}131 \\
168 \\
129 \\
116 \\
89 \\
70 \\
100 \\
180 \\
119 \\
207 \\
140 \\
214 \\
139\end{array}$ \\
\hline
\end{tabular}

FEV $=$ one-second forced expiratory volume; $\mathrm{VC}=$ slow vital capacity; $\mathrm{TLC}=$ total lung capacity; $\mathrm{V}_{\mathrm{A}}=$ alveolar volume; $\mathrm{Kco}=$ transfer coefficient; TLCO = carbon monoxide diffusing capacity (transfer factor).

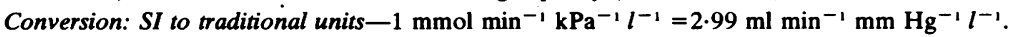




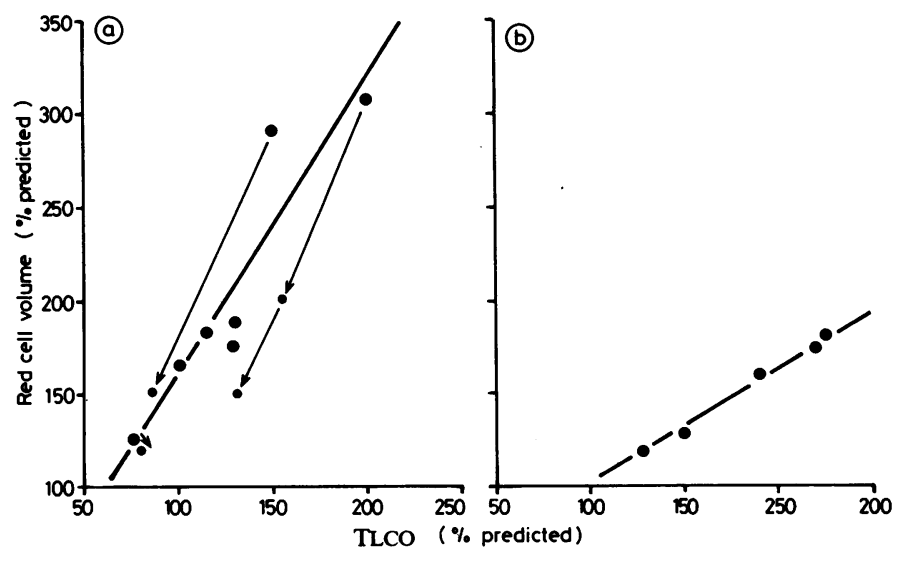

Fig $1 a$ Comparison of red cell volume and total lung diffusing capacity of seven men with polycythaemia rubra vera. Results are expressed as percentages of predicted values. Changes after treatment are shown for three patients on whom further measurements were made after 6-12 months.

Fig $1 b$ Comparison of red cell volume and total lung diffusing capacity for five women with polycythaemia rubra vera. Results are expressed as percentages of predicted values. and the red cell volume, both expressed as percentage of predicted, ${ }^{10}{ }^{11}$ for the seven men $(r=0.92$, $p$ $<0.01)$ (fig $1 a)$ and the five women $(\mathrm{r}=0.99, \mathrm{p}<$ 0.001 ) (fig 1b).

Measurements of DM and Vc on patients 1 and 2 showed that the pulmonary capillary volume was above our laboratory's normal range $(50-70 \mathrm{ml})$. After treatment of their polycythaemia rubra vera the Vc became normal (fig 2).

\section{Discussion}

Burgess and Bishop ${ }^{3}$ and Herbert et al ${ }^{4}$ attributed the increased TLCO in their patients with polycythaemia rubra vera to the increased haemogolobin concentration. Our data, however, suggest that it remains raised even after correction

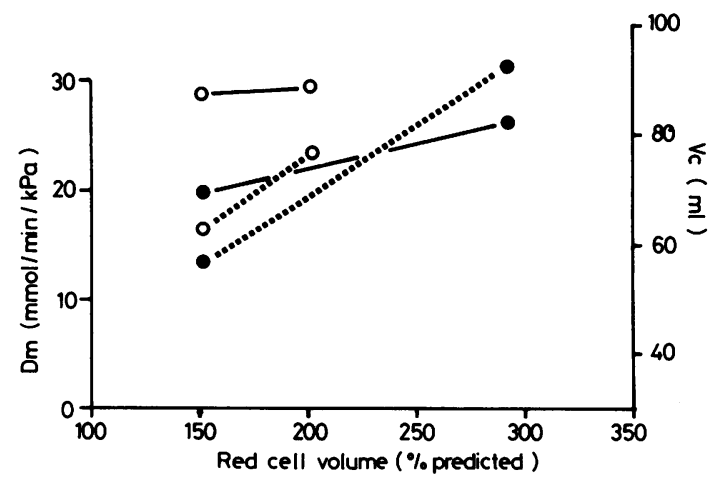

Fig 2 Changes in pulmonary capillary blood volume, VC (--.-), and membrane conductance, DM (patients $1(\bullet)$ and $2(0)$, compared with change in red cell volume, after treatment for polycythaemia rubra vera. Conversion: SI to traditional units $-1 \mathrm{mmol} \mathrm{min} \mathrm{m}^{-1} \mathrm{PPa}^{-1}$ $=2.99 \mathrm{ml} \mathrm{min}^{-1} \mathrm{~mm} \mathrm{Hg}^{-1}$.

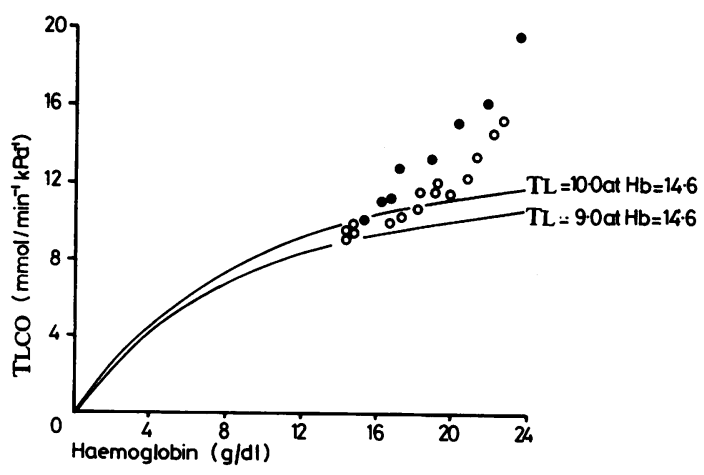

Fig 3 Serial measurements of the total carbon monoxide diffusing capacity of the lung (TLCO) compared with haemoglobin concentration for patients 1 (०) and $2(0)$ after treatment of polycythaemia rubra vera. For the two isopleths, corresponding to constant values of $D M$ and $V C$ (with a $D M / V C$ ratio of 0.7$)$ (-), the variation in $T L C O$ as haemoglobin concentration alters is a function only of changes in $\theta$. Note that the fall of the patients' TLCO is greater than would be predicted from such isopleths.

to a standard haemoglobin concentration of 14.6 g/dl (table 2). This difference may be related to coexistent pulmonary disease since some of the patients of Burgess and Bishop had abnormal pulmonary function tests after treatment of their polycythaemia rubra vera, which the authors interpreted as being consistent with pulmonary thrombotic disease and reduction of the pulmonary vascular bed. On clinical, radiographic, and pulmonary function criteria our patients did not have significant lung disease. The TLCO values are out of proportion to the raised haemoglobin concentration. Serial studies on patients 1 and 2 support this idea. In fig 3 serial values for TLCO during treatment are plotted against haemoglobin concentration. The TLCO fell 
at a greater rate in relation to the haemoglobin concentration than would be predicted from the isopleths corresponding to a constant DM and VC. Although the haemoglobin correction factor assumes a $\mathrm{DM} / \mathrm{VC}$ ratio of $0 \cdot 7$, the correction factor changes by less than $5 \%$ if the $\mathrm{DM} / \mathrm{Vc}$ ratio is halved or doubled.

The Roughton-Forster equation' predicts that after a correction for the reaction rate $(\theta)$ has been made, a further increase in TLCO must be due to an increase in the membrane conductance or capillary blood volume. On theoretical grounds an increase in Vc would seem the more likely explanation. Our data on changes in DM and VC following treatment (fig 2) for patients 1 and 2 support this suggestion. Should the pulmonary capillary bed be reduced by pulmonary vascular disease or emphysema, its capacity for expansion is likely to be reduced. In this case the TLCO (corrected) for haemoglobin concentration may show little or no increase when polycythaemia occurs. In one patient with polycythaemia rubra vera who had clinical and radiological $^{12}$ evidence of emphysema, the VC was markedly reduced and did not change after treatment for his polycythaemia rubra vera (data not shown). The change in his TLCO after treatment was entirely explained by the change in haemoglobin concentration.

In patients with polycythaemia rubra vera who have no significant pulmonary disease the pulmonary capillary blood volume appears to share the expansion in overall blood volume. Thus the single-breath TLCO test may act as a convenient and simple monitor for the response of the disease to treatment.

\section{References}

' Roughton FJW, Forster RE. Relative importance of diffusion and chemical reaction in determining rate of exchange of gases in the human lung, with special reference to true diffusing capacity of pulmonary membrane and volume of blood in the lung capillaries. J Appl Physiol 1957;11:290-302.

${ }^{2}$ Ratto O, Briscoe WA, Morton JW, Comroe JH. Anoxemia secondary to polycythemia and polycythemia secondary to anoxemia. Am J Med 1955;19:958-65.

${ }^{3}$ Burgess JH, Bishop JM. Pulmonary diffusing capacity and its sub-divisions in polycythaemia vera. J Clin Invest 1963;42:997-1006.

4 Herbert SJ, Weill H, Stuckey WJ, Urner C, Gonzales E, Ziskind MM. Pulmonary diffusing capacity in polycythaemic states before and after phlebotomy. Dis Chest 1965;48:408-15.

5 Cotes JE, Dabbs JM, Elwood PC, Hall AM, McDonald A, Saunders MJ. Iron deficiency anaemia: its effect on transfer factor for the lung (diffusing capacity) and ventilation and cardiac frequency during submaximal exercise. Clin Sci 1972;42: 325-35.

- Clark EH, Woods RL, Hughes JMB. Effect of blood transfusion on the carbon monoxide transfer factor of the lung in man. Clin Sci Mol Med 1978;54:627-31.

${ }^{7}$ Berlin NI. Diagnosis and classification of the polycythaemias. Semin Haematol 1975;12:339-51.

- Goldman HI, Becklake MR. Respiratory function tests. Normal values at medium altitudes and the prediction of normal results. Am Rev Tuberc Dis 1954;79:457-67.

- Cotes JE. Lung function: assessment and application in medicine. 4th ed. Oxford: Blackwell Scientific Publications, 1979:223-9.

${ }^{10}$ Bradley J, Bye C, Hayden SP, Hughes DTD. Normal values of transfer factor and transfer coefficient in healthy males and females. Respiration 1979;38:221-6.

"Hurley PJ. Red cell and plasma volumes in normal adults. J Nucl Med 1975;16:46-52.

12 Thurlbeck WM, Simon G. Radiographic appearance of the chest in emphysema. Am J Roentgenol 1978;130:429-40. 